\title{
UFT並びにS-1のワルファリンとの 相互作用による血液凝固能変動に関する比較検討
}

\author{
高瀬尚武 ${ }^{* 1}$, 藤原聡子 ${ }^{2}$, 中田日早枝 ${ }^{1}$, 三木育子 ${ }^{1}$, 千㟝昭輝 ${ }^{1}$, 樋本䒽子 $^{1}$ \\ 松永 尚 ${ }^{2}$, 千堂年昭 ${ }^{2}$, 室井延之 ${ }^{1}$ \\ 赤穂市民病院薬剂部 ${ }^{1}$, 岡山大学病院薬剂部 ${ }^{2}$
}

\section{Investigation of Drug Interaction between Warfarin and UFT or S-1}

\author{
Naotake Takase ${ }^{* 1}$, Satoko Fuziwara ${ }^{2}$, Hisae Nakata ${ }^{1}$, Ikuko Miki ${ }^{1}$, Shoki Senzaki ${ }^{1}$ Mayuko Himoto ${ }^{1}$, \\ Hisashi Matsunaga', Toshiaki Sendo ${ }^{2}$ and Nobuyuki Muroi ${ }^{1}$ \\ Department of Pharmacy, Ako City Hospital ${ }^{1}$, \\ Department of Pharmacy, Okayama University Hospital ${ }^{2}$ \\ $\left[\begin{array}{l}\text { Received July 3, } 2012 \\ \text { Accepted October 22, } 2012\end{array}\right]$
}

Fluoropyrimidines (FU) in combination with warfarin (WF) are reported to increase prothrombin time-international normalized ratio (PT-INR) and bleeding. In the present study, we investigated retrospectively the timing of expression of blood coagulation abnormality in 11 patients treated with WF and UFT or S-1 concomitantly in Okayama University Hospital and Ako City Hospital. In 11 patients, 6 were UFT in combination with WF (UFT group), 5 were S-1 in combination with WF (S-1 group). In all patients, PT-INR was significantly increased after combination with UFT or S-1. The PT-INR elevated rate of the S-1 group was $214.5 \%$ and its rate of the UFT group was $178.2 \%$. The PT-INR elevated rate was higher in the S-1 group than in the UFT group. The PT-INR was increased 2.8 times after four months in the UFT group. These results suggest that the careful monitoring of PT-INR elevation and bleeding is necessary in patients receiving UFT in combination with WF as well as S-1 in combination with WF.

Key words — warfarin, UFT, S-1, prothrombin time-international normalized ratio (PT-INR)

\section{緒言}

フルオロウラシル系抗がん剤 $(\mathrm{FU})$ とワルフ アリン（WF）との併用においては，WFの抗凝 固作用が増強されることが知られており, prothrombin time-international normalized ratio (PTINR）の上昇や出血症状に注意が必要である. FUと WF との併用による PT-INR上昇の発現時 期および程度についての報告は, FUの種類によ り異なっており，相互作用の発現機序の詳細も明 らかではない. カペシタビンと WF との併用にお いては, PT-INR 上昇や出血症状は併用開始数日 後から投与中止後 1 力月以内の期間に発現し,

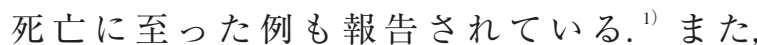
5-fluorouracil（5-FU）の代謝経路に関与している dihydropyrimidine dehydorogenase（DPD）の阻害 作用を有する DPD-inhibitory fluoropyrimidine (DIF) であるテガフール・ギメラシル・オテラシルカリ ウム配合剂（S-1）は，胃がん，結腸・直腸がん， 頭頸部がん, 非小細胞肺がん, 手術不能または再 発乳がん, 膵がん, 胆道がんに適応を有し, 現在, 幅広く使用されているが, WF 併用時における相 互作用に注意が必要である。

S-1 と WF 併用では，PT-INR 上昇は，複数の報 告で, 併用約 2 週間後より認められ, PT-INR 最 高值は 1.6〜2.6 倍に増加することが示されてい

*兵庫県赤穂市中広 1090 
る. ${ }^{2,3)} し$ し, 同じ DIF で, 頭頸部がん, 胃がん, 結腸・直腸がん, 肝蔵がん, 胆のう・胆管がん, 脺がん, 肺がん, 乳がん, 膀胱がん, 前立腺がん, 子宮頸がんに適応をもち，結腸・直腸がんにおい てはホリナートとの併用療法としても広く使用さ れているテガフール・ウラシル配合剤（UFT） においては，今までにWF との相互作用の発現時 期について調べた報告はない.

今回, UFT 並びに S-1 の WF との相互作用によ る血液凝固能変動の違いを明らかにするために, UFT 並びに S-1 服用患者において比較検討した。

\section{方 法}

\section{1. 対象患者}

岡山大学病院および赤穂市民病院において, 2008 年 4 月〜 2009 年 3 月の期間に WF と UFT ま たは S-1 を併用した全ての患者 12 名を抽出した. FU 投与前から WF を投与していた 11 名を解析対 象とし，S-1 投与中に WF を追加投与した 1 名を 解析対象から除外した。 そして, 解析対象の 11 名を，WFとUFT の併用患者 6 名（UFT 群）, $\mathrm{WF}$ と S-1 の併用患者 5 名 (S-1 群) の 2 群に分 類した。なお本研究は, 岡山大学病院倫理委員会 および赤穂市民病院倫理委員会の承認を得て実施 した。

\section{2. 調查方法}

対象患者の背景（年歯令, 性別, 疾患, FU 投与 目的，FU 投与量，WF 投与量, PT-INR, Aspartate aminotransferase (AST), Alanine aminotransferase (ALT)，血清クレアチニン值（Scr），その他の 併用薬）および併用後の PT-INR 上昇の発現時期 と程度について診療録よりレトロスペクティブに 調査し, UFT 群と S-1 群を比較解析した。

\section{3. 統計学的解析}

2 群間の比較は, 性別については Fisher の正確 確率検定，その他は Mann-Whitney の $U$ 検定を用 い，各群での WF 投与量と PT-INR の併用前後の 比較は，対応のある $t$-検定を用いて実施した，有 意水準は危険率 5\%未満とした。

\section{結＼cjkstart果}

\section{1. 患者背景}

対象患者の背景を表 1 に示す。UFT 群が 6 名, S-1 群が 5 名の計 11 名で, 年齢, 性別とも両群 間に有意な差は認めなかった。FUの投与量は, UFT 群 が $333.3 \pm 51.6 \mathrm{mg} /$ 日, S-1 群 が $96.0 \pm$ $16.7 \mathrm{mg} /$ 日と, 両群とも投与量は適正範囲内であ った。また，UFT 群の大腸がんの 2 名において はホリナートとの併用療法であったが, ほかの 9 名は FU 単独療法であった。 併用開始時の WF 投 与量は, UFT 群が $3.29 \pm 1.83 \mathrm{mg} /$ 日, S-1 群が $2.70 \pm 0.76 \mathrm{mg} /$ 日であり, 両群間に差はなかった。 併用前の ALTにおいて両群間で有意差が認めら れたが，正常值の範囲内であった．WFの作用を 増強する可能性が添付文書に記載されている薬剤 を併用していた症例は 9 例（UFT 群 5 例, S-1 群 4 例）で, 服用薬剤としてはアスピリン，オメプ ラゾール，ロキソプロフェンなどであった。 しか し, 調査期間中, 全ての症例において, WFの作 用を増強する可能性がある薬剂の追加や用量変更 はなく,肝機能（AST, ALT）および腎機能（Scr） にも異常はみられなかった。

\section{2. 併用後の血液凝固能の変動について}

UFT 群，S-1 群で WF を併用開始後, 全ての症 例においてPT-INR の上昇が認められた。図1に 示すように, UFT 群では併用前の PT-INR は 1.66 \pm 0.71 に対して併用後の最高值は $4.09 \pm 1.47(P$ $=0.0098)$, S-1 群では併用前の PT-INR は $1.87 \pm$ 0.67 に対して併用後の最高值は $4.77 \pm 1.86 （ P$ =0.026）で，両群とも有意に上昇した。

表 2 にPT-INR 上昇率と併用開始から WF の減 量または休薬までの期間および PT-INR 最高值に 達するまでの期間を示す。 UFT 群と S-1 群の PTINR上昇率を比較すると, UFT 群が $178.2 \pm$ $155.0 \%$, S-1 群が $214.5 \pm 250.0 \%$ で, UFT 群の 方が低值であったが有意差は認められなかった。 併用開始から WF の減量または休薬までの期間に ついては, UFT 群, S-1 群の全ての症例で WF の 減量または休薬が行われており, UFT 群が 107.2 土97.2 日, S-1 群が $17.4 \pm 12.4$ 日で, UFT 群の 
表 1 UFT 群と S-1 群の患者背景

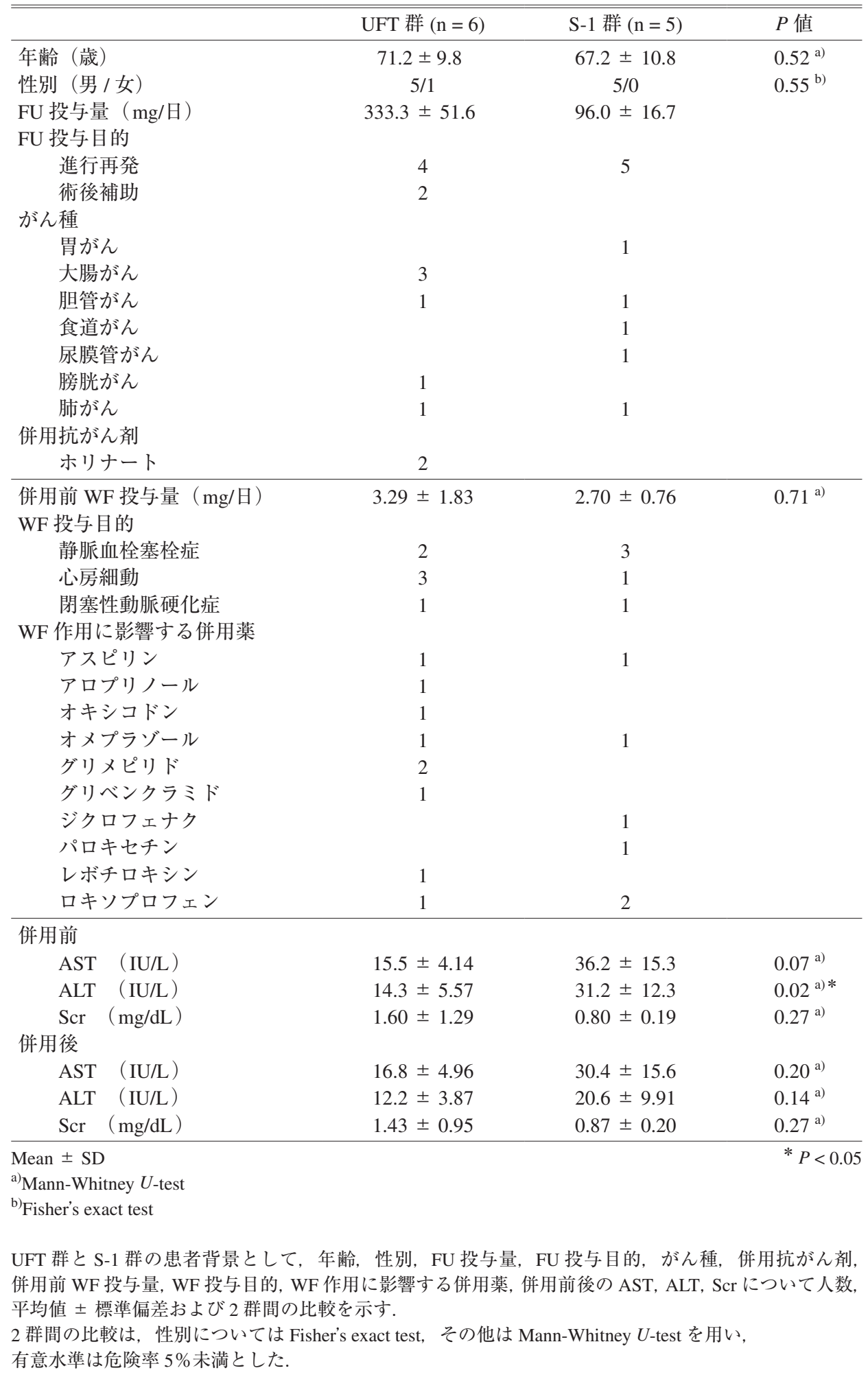

方が有意に長かった $(P=0.011)$ ．また，併用開 始から PT-INR 最高值に達するまでの期間を比較 すると, UFT 群が $117.2 \pm 89.8$ 日, S-1 群が 20.8 \pm 13.0 日で, WF の減量後も PT-INR は上昇し続け, UFT 群のほうが有意に長かった $(P=0.006)$.
減量後の WF 投与量は, UFT 群が $2.08 \pm 1.45$ $\mathrm{mg}, \mathrm{S}-1$ 群が $1.20 \pm 1.15 \mathrm{mg}$ で, UFT 群と S-1 群 の WF 減量率を比較すると, UFT 群が $39.2 \pm$ $18.0 \%$ ，S-1 群が $59.3 \pm 37.8 \%$ で両群間に有意差 は認められなかった。 


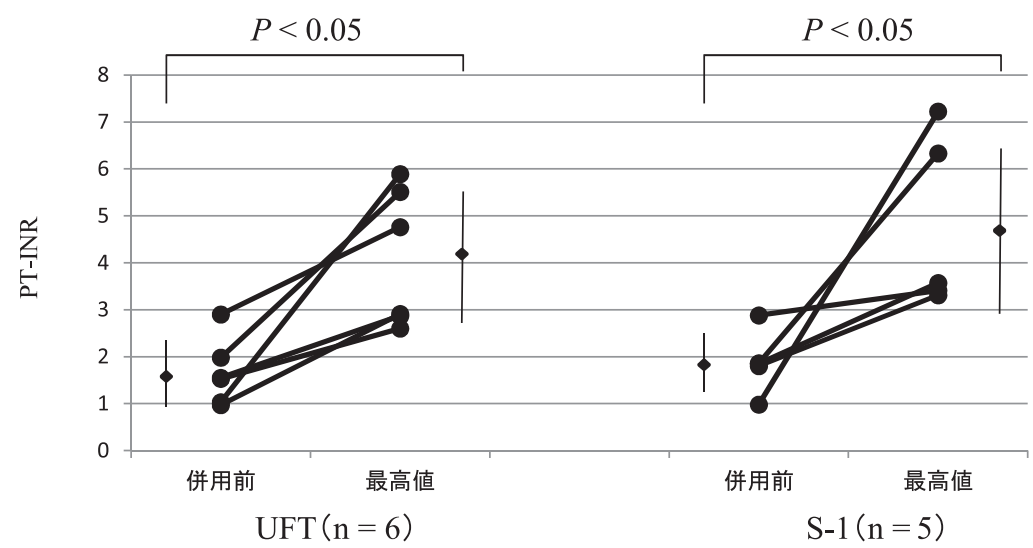

図 1 PT-INR の併用前と併用後最高值の比較

UFT 群と S-1 群における PT-INR の併用前と併用後最高值の比較を示す。

併用前と最高值の比較は，対応のある $t$-検定を用いて実施し，有意水準は危换率 $5 \%$ 未満とした

表 2 PT-INR 上昇率と併用開始から WF 減量または休薬までの期間および PT-INR 最高值に達す るまでの期間

\begin{tabular}{|c|c|c|c|}
\hline & UFT 群 $(\mathrm{n}=6)$ & $\mathrm{S}-1$ 群 $(\mathrm{n}=5)$ & $P$ 值 \\
\hline PT-INR 上昇率（\%） & $178.2 \pm 155.0$ & $214.5 \pm 250.0$ & $0.855^{\text {a) }}$ \\
\hline WF 減量または休薬までの期間（日） & $107.2 \pm 97.2$ & $17.4 \pm 12.4$ & $0.011^{\text {a) } *}$ \\
\hline PT-INR 最高值に達するまでの期間（日） & $117.2 \pm 89.8$ & $20.8 \pm 13.0$ & $0.006^{\text {a) } * *}$ \\
\hline
\end{tabular}

併用前から併用後最高值までの PT-INR 上昇率と併用開始から WF の減量または休薬までの期間および PT-INR 最高值に達するまでの期間と 2 群間の比較を示す.

2 群間の比較は, Mann-Whitney $U$-test を用い, 有意水準は危険率 5\%未満とした.

UFT 群の 1 症例を図 2 に示す。併用 29 日目に PT-INR の上昇と鼻出血により WF 休薬，その後ビ タミン K の投与が行われ，UFT の投与は中止とな った。

S-1 群においては，S-1 開始前からWF を投与 していた症例を解析対象としたが，今回，解析対 象から除外した S-1 投与中にWF を追加投与した 1 症例においては，併用開始直後に急激な PT-INR の上昇が認められ，併用 7 日目にWF 休薬，そし て減量によってもコントロールが困難となり，ビ タミン $\mathrm{K}$ の投与が行われた（図 3）.

\section{考察}

近年, S-1 と WF の相互作用による PT-INR 上 昇の症例が報告されているが, ${ }^{2-4)}$ 同じ DIF の UFT
と WF との報告はない． FU と WF との併用によ る PT-INR 上昇の発現時期および程度についての 報告は, FUの種類により異なっており, 相互作 用の発現機序の詳細も明らかではない。 そこで, UFT においても WF との相互作用が起こるのか, また，相互作用の発現経過が S-1 と同様なのかを 調べるために, WF と UFT 並びに S-1 併用患者に おいて血液凝固能変動を比較検討した.

今回の調査では, UFT 群 6 例, S- 1 群 5 例の 11 例全ての症例で PT-INR の上昇が認められた．S-1 については, 今回の調查症例の 5 例において, 平 均約 3 週間で PT-INR が約 3.1 倍上昇した。一方, UFT については, 今回の調査症例の 6 例において, 併用開始 2 週間ごろより相互作用が発現し, S-1 より遅いものの, 平均約 4 カ月で PT-INR が約 2.8 倍上昇し, WF の減量後も PT-INR は上昇し続け, 

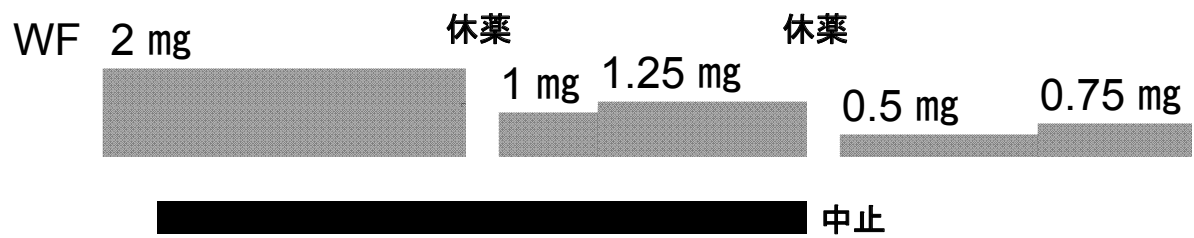

2/6 UFT $300 \mathrm{mg}$

中止

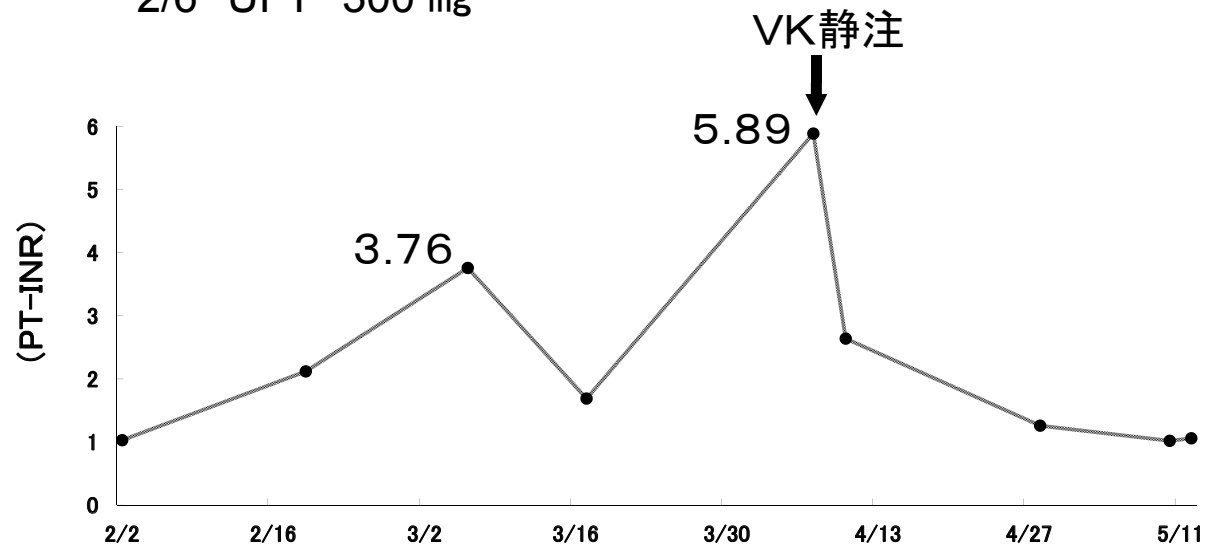

図 $2 \mathrm{WF}$ にUFT を追加した症例の PT-INR の変化

UFT の中止に至った症例の UFT と WF の投与状況と PT-INR の変動状況を示す.
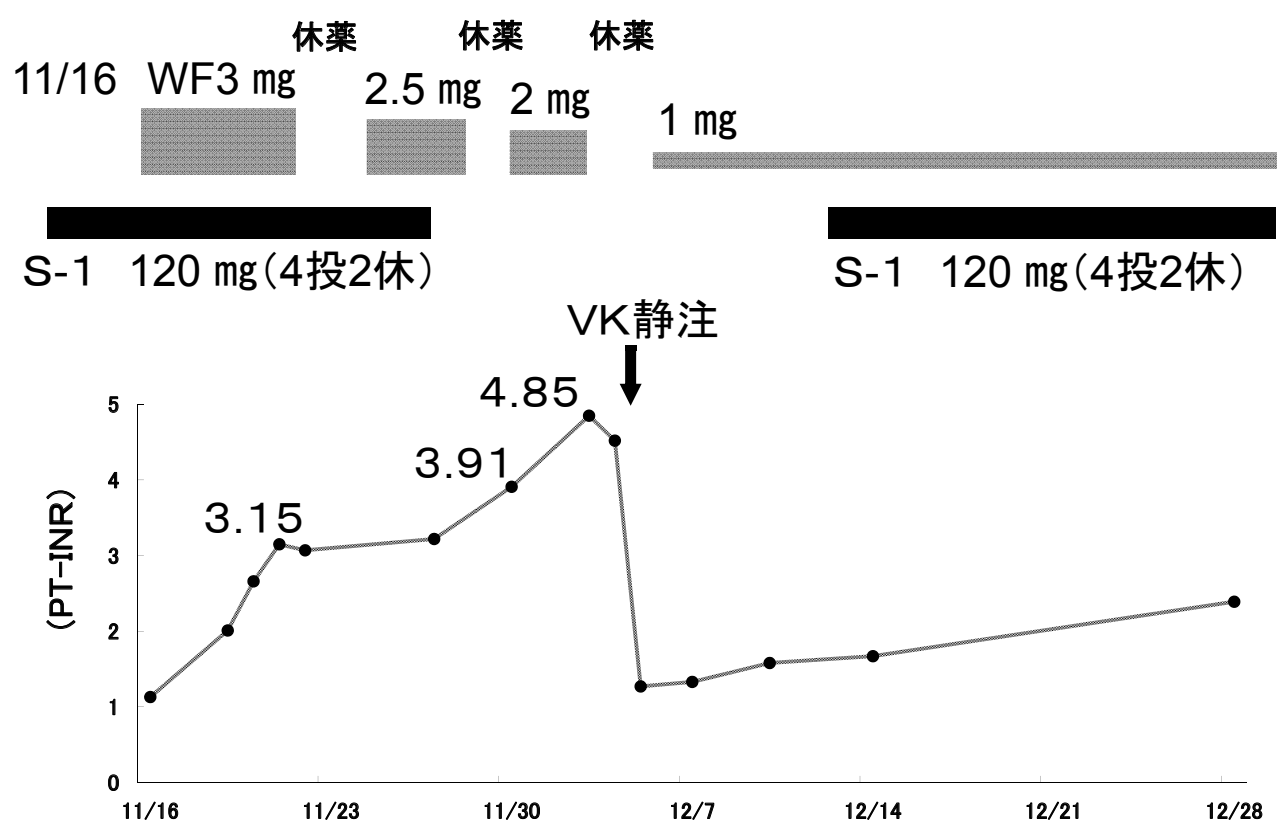

図 3 S-1 にWF を追加した症例の PT-INR の変化

S-1 にWF を追加した症例の S-1 と WF の投与状況と PT-INR の変動状況を示す.

S-1 と同様, リスクは非常に高いことが確認された.

WF は一対の光学異性体を等量含有するラセミ 体であり，抗凝固作用に関与するのは主として S- 体である。遊離型 S- 体 WF の体内動態は，血 漿蛋白結合率の変化に依存しない肝固有クリアラ ンス，つまり肝代謝にかかわる肝代謝酵素活性に 依存している。 cytochrome P-450（CYP）2C9 は
S- 体 WF の主要代謝経路である 7 位および 6 位 の水酸化反応の $80 \%$ 以上を担うとされており, $\mathrm{WF}$ の薬効の個人間変動の原因にかかわる肝クリ アランスの大部分は CYP2C9 の活性の変動に依 存するとされている. ${ }^{5}$

ヒトにおける FUと WF の相互作用の発現機序 は，5-FUあるいは5-フルオロヌクレオチドなど 
によるCYP2C9 の DNA 合成阻害作用や RNA 機 能障害により, 肝酵素蛋白の合成が減少し, WF 代謝酵素量減少により，WF の作用が増強すると 考えられている。 ${ }^{6}$ また，S-1 の配合成分であるギ メラシルは，UFT の配合成分であるウラシルに 比べて 5-FU の分解を約 200 倍強く拮抗阻害し, S-1 では UFT に比べて生体内 5-FU 濃度が著明に 上昇しかつ長時間持続する. ${ }^{7}$

これらのことから, 今回の我々の調査において, UFT が S-1 に比べて相互作用の発現時期が遅かっ たのは, 5-FUの血中濃度と持続時間の違いが, WF 代謝における CYP2C9 活性へ影響しているも のと推察される. また, ラットの肝ミクロソーム を用いた検討において，5-FUの $120 \mathrm{mg} / \mathrm{kg}$ 単回腹 腔内投与と $24 \mathrm{mg} / \mathrm{kg} /$ 日の 5 日間連続腹腔内投与後 の CYP2C11 および CYP3A の発現量を比較した結 果，単回投与では投与 7 日後までに CYP の発現 量に変化は認められなかったが, 連続投与では投 与終了 4 日後, 7 日後に CYP の発現量が減少した ことが報告されている. ${ }^{8}{ }^{8}$-FU のプロドラッグであ る UFTに扔いても，長期間の連続投与により WF 代謝酵素量が減少し, WF との相互作用が増強し たものと推察されるが, 今後, 薬物動態学的な視 点からも検証する必要があると考える。

また，S-1 投与中に WF を追加投与した症例は 今までに報告されていなかったが，今回の症例で は, 併用開始直後に急激な PT-INR の上昇が認め られ，WFコントロールが困難であった．WFと 同じく CYP2C9で代謝されるフェニトイン (PHT) と S-1 の相互作用発現における報告では，S-1 が 先行投与されていた患者にPHTが併用された場 合は，PHT を先行投与されていた患者に S-1 を併 用した場合に比べ，早期に PHT 濃度が中毒域に 達したとされている.9) これらのことから， S-1を 先行して服用していた場合は，すでにWF 代謝阻 害が生じているおそれがあり，WF 投与量を予定 より減量して開始することが望ましいと思われる.

がん患者は, 静脈血栓症の発症頻度が高く, ${ }^{10}$ 我が国では静脈血栓症, 心筋梗塞症, 肺塞栓症, 脳血栓症等の血栓塞栓症の治療および予防にWF が抗凝固療法として広く使用されている。出血は WF 治療で最も多い合併症であり, 大出血の発生
は年に打よそ $5 \%$ と報告されているが, ${ }^{11)}$ 抗凝固 治療の不十分な管理や WF との薬物相互作用が危 険性を増大させるといわれている。. ${ }^{12)}$

5-FU と WF の併用においての WF の用量調節の 報告としては, Chlebowski らは, 併用開始 3 日目 にWFの用量調節を行い, 用量が安定したら週 1 回モニターしながら, 必要時WFの用量を調節し

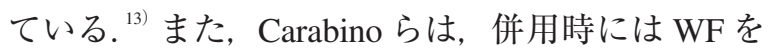
20〜 70\%減量する必要があり, また 5-FU 投与終了 後 30 日以内はプロトロンビン時間を標準域に維持 するため，逆にWF を増量するとしている. ${ }^{14)}$

今回の調査より, WF 併用時の UFT 投与にお いても PT-INR の上昇を認め, 血液凝固能の変動 と出血症状の副作用モニタリングが必要であるこ とが明らかとなったＦUである5-FU，カペシタ ビン, S-1 のみならず，UFT においてもWFとの 併用にあたっては, WF の減量も考慮し, 血液凝 固能の変動拉よび出血傾向に注意してモニタリン グを頻回に行うことが必要である.

\section{引用文献}

1) Saif MW, An adverse interaction between warfarin and fluoropyrimidines revisited, Clin Colorectal Cancer, 2005, 5, 175-180.

2）五十嵐弘幸, 前田康裕, 笠松依子, 福山公美子, 寺下朋江, 伊藤妃佐子, 水野賀夫, 佐野正毅, 高嶋孝次郎, S-1とワルファリンの薬物相互作用 についての検討, 日本病院薬剤師会雑誌, 2009, 45, 1321-1324.

3）山田孝明, 渡邊裕之, 矢野貴久, 野中敏治, 高田 淳史, 園田正信, 窪田敏夫, 江頭伸昭, 大石了三, WarfarinとS-1併用患者における血液凝固能異常 の発現時期に関する検討, 薬学雑誌, 2010, 130, 955-960.

4）安井友佳子, 西口智子, 山本明紀, 藤井千賀, 藤野 美佐子, 柘植麻紀子, 大野雅子, 東 純一, 松村 多恵, 大里浩樹, 阿南節子, 古河 洋, S-1 と Warfarinの併用により出血傾向となった 1 症例, 癌と化学療法, 2008, 35, 1367-1370.

5) Kaminsky LS, Zhang ZY, Human P450 metabolism of warfarin, Parmacol Ther, 1997, 73, 67-74.

6) Brown MC, An Adverse Interaction between Warfarin and 5-Fluorouracil, Chemotherapy, 1999, 45, 
392-395.

7）白坂哲彦, 島本雄司, 加藤利幸, 福島正和, Biochemical Modulationを応用した腫瘍選択毒性 の高い新規5-Fluorouracil系抗癌剂S-1の基礎的 研究, 癌と化学療法, 1998, 25, 371-384.

8) Stupans I, Richards DA, McClure MT, Effects of 5-Fluorouracil treatment on rat liver microsomal enzymes, Xenobiotica, 1995, 25, 1-8.

9）井出貴之, 勝山善彦, 小川由則, 酒井圭一, 本郷 一博, 松永民秀, 大森 栄, S-1によるフェニトイ ン中毒の早期発現症例, 日本病院薬剤師会雑誌, 2010, 46, 789-791.

10) Prandoni P, How I treat venous thromboembolism in patients with cancer, Blood, 2005, 106, 4027-4033.
11) Gitter MJ, Jaeger TM, Petterson TM, Gersh BJ, Silverstein MD, Bleeding and thromboembolism during anticoagulant therapy, Mayo Clinic Proceedings, 1995, 70, 725-733.

12）ベネット, ブラウン, ローレンス臨床薬理学, 西 村書店, 東京, 2006, pp.469-472.

13) Chlebowski RT, Gota CH, Chan KK, Weiner JM, Block JB, Bateman JR, Clinical and pharmacokinetic effects of combined warfarin and 5-fluorouracil in advanced colon cancer, Cancer Res, 1982, 42, 4827 4830 .

14) Carabino J, Wang F, International Normalized Ratio fluctuation with warfarin-fluorouracil therapy, Am J Health Syst Pharm, 2002, 59, 875. 